\title{
The interaction of nitrogen supply and plant density in potatoes
}

\author{
K. B. A. Bodlaender and A. J. Reestman
}

Institute for Biological and Chemical Research on Field Crops and Herbage (IBS), Wageningen, The Netherlands

Research and Advisory Institute for Field Crop and Grassland Husbandry (PAW), Wageningen, The Netherlands

Received 15 May, 1968

\section{Summary}

The interaction of nitrogen supply and plant density on potatoes was investigated in experiments with the late variety Alpha on sandy soils. In the years 1959, 1960 and 1961 series of plant densities varying from 10,000 to 200,000 plants/ha (seed size $35 / 45 \mathrm{~mm})$ were planted at three nitrogen levels $(0,100$ and $200 \mathrm{~kg} \mathrm{~N} / \mathrm{ha})$ and lifted at the end of the growing period. In 1962 three plant densities: 40,000, 80,000 and 160,000 plants/ha (seed size $35 / 45 \mathrm{~mm}$ ) were planted at the same three nitrogen levels and lifted on 4 dates during the growing period.

In the experiments of 1959-1961 total tuber yield increased with plant density up to 70,000 to 100,000 plants/ha. With very dense plantings a decrease in yield was found when no nitrogen was supplied and a small or no increase with nitrogen doses of 100 and $200 \mathrm{~kg} /$ ha.

The optimal plant density was increased by a nitrogen dose of $100 \mathrm{~kg} \mathrm{~N}$ compared to no nitrogen supply; a further increase of the nitrogen supply did not change the optimal plant density.

An increase in nitrogen supply was most effective at high plant densities, especially after a long growing period: for instance in the experiment of 1962 the high nitrogen - high plant density plots obtained the highest final tuber yield.

Such a favourable interaction of nitrogen supply and plant density on yield was usually not obtained in early liftings. The final yields in the experiments of 19591961 may be regarded to come from relatively early liftings, because growth was disturbed by drought or stopped early by Phytophthora.

The weights of tubers $>35 \mathrm{~mm}$ and the total tuber dry weights generally showed the same effects of nitrogen and spacing as the total tuber fresh weights.

\section{Introduction}

The yield of potatoes per ha generally increases with increasing plant density until a maximum is reached. A potato plant is composed of a number of stems. A good correlation between the number of main stems per ha and tuber yield per ha was demonstrated by Reestman and de Wit (1959).

Several restricting factors as water supply or mineral nutrition may possibly inhibit a further increase in tuber yield at high plant densities. Under certain conditions a further increase in plant density can even lead to a decrease in tuber yield (Reest- 
man, 1953). Roztropowicz (1965) showed that in Poland water supply is one of these factors in those cases in which low yields were obtained (10-20 tons/ha).

Therefore one may expect the optimum of plant density to be achieved at lower plant densities in conditions under which low yields are obtained than under more favourable soil conditions. Some authors, however, presented data contrary to this opinion. De Wit (1960) arrived at the general conclusion — for beets and small grains - that the relative effect of plant density on yield is high when yields are low. According to de Wit it is advantageous to plant densely under conditions of low yields and where yield depressions due to dense planting do not occur.

These conclusions correspond with the ideas of Klapp (1950). He advised for potatoes the following plant densities at different soil fertility:

$\begin{array}{ll}\text { high fertility } & 30,000-40,000 \text { plants per ha } \\ \text { moderate fertility } & 40,000-50,000 \text { plants per ha } \\ \text { low fertility } & 50,000-60,000 \text { plants per ha }\end{array}$

Dutch potato growers, however, generally plant at the same density on soils of different fertility. Dense planting - sometimes over 60,000 plants/ha - is practized only for seed potato growing to obtain a favourable tuber size distribution.

Fertility is a result of nitrogen content of the soil before planting, nitrogen fertilization and nitrogen mineralization during growth, sufficient supply of other nutrients and water as well as compaction and aeration of the soil. Van der Paauw (1962) in the Netherlands and Tamm (1950) in Germany found a good correlation between the yields in a given year and the weather conditions in the preceding year: lower yields were obtained after a wet year than after a dry one probably because less nitrogen will remain in the soil after a wet winter.

In the Netherlands experiments on the interaction of nitrogen supply and plant density were carried out in the years 1940-1942 by the Agricultural Extension Service (summarized by Reestman and Van Dobben, 1943). No difference in reaction of tuber yield to plant density at different nitrogen levels was found in the mean of 25 experiments; in all these experiments a positive effect of nitrogen on tuber yield was shown.

In some of these and many other experiments dense plantings matured earlier than less dense ones, also under fertile conditions. Since generally the effect of nitrogen on tuber yield can partly be ascribed to a longer productive period of the foliage, it may be assumed that shortage of nitrogen may occur sooner at high than at low plant densities. A different effect on tuber yield of the nitrogen dressing at different plant densities may be expected. This interaction of nitrogen supply and plant density was studied by the authors more closely in some field experiments.

\section{Description of experiments}

The experiments were carried out on sandy soil near De Steeg (1959), Leersum (1960 and 1961) and Hummelo (1962). Presprouted seed potatoes of the late variety Alpha, seed size $35 / 45 \mathrm{~mm}$, were planted with a row distance of $66.7 \mathrm{~cm}$.

In the experiments of 1959,1960 and 1961 series of plant densities (varying from 10,000 to 200,000 plants per hectare) at three nitrogen doses $(0,100$ and $200 \mathrm{~kg}$ $\mathrm{N} /$ ha, applied as ammonium nitrate limestone shortly after planting) were planted in April and lifted at the end of the growing season. In the experiment of 1962 three 
plant densities $(40,000,80,000$ and 160,000 plants/ha) at the same three nitrogen doses were compared and lifted at four dates: 22 June, 26 July, 24 August and 9 October.

The net surface of the plots was $10 \mathrm{~m}^{2}$ in the experiments of 1959-1961, only the 10,000 plants/ha plots were four times as large as the other ones. In the experiment of 1962 all plots had a net surface of $6 \mathrm{~m}^{2}$. The treatments were laid down in triplicate.

In the experiments of 1959,1960 and 1961 tuber fresh weight and in the experiment of 1962 fresh and dry weight and nitrogen uptake of foliage, tubers and other underground parts (underground stems, stolons and roots) were determined; the data of this rest fraction will not be discussed here. In all experiments tuber size distribution was also recorded.

\section{Results}

Tuber yield at the end of the growing period

In the experiments of 1959, 1960, 1961 and 1962 total tuber yield and yield of tubers $>35 \mathrm{~mm}$ per hectare increased with increasing plant density until an optimum was achieved (Fig. 1a and 1b). In all these experiments the optimum is achieved at lower plant densities without nitrogen supply than with a nitrogen dose of $100 \mathrm{~kg}$ $\mathrm{N} / \mathrm{ha}$; a further increase in nitrogen to $200 \mathrm{~kg} \mathrm{~N} /$ ha did not change the optimal plant density.

The difference in optimal plant density between the no nitrogen and nitrogen-fertilized plots may possibly have been caused by the influence of nitrogen on the number of main stems developing from the seed potatoes. The same results are however visible if the tuber yields are plotted against the number of main stems per hectare counted at the end of the growing period (Fig. 1c).

The interaction between nitrogen supply and plant density showing in the graphs is not in all experiments significant, as Table 1 shows. Weather conditions, water supply and attack by diseases were different in these four years. Some of these differences may explain the differences which can be observed in the graphs (Fig. 1).

In all years at normal plant density good tuber yields were obtained also when no

Table 1 Levels of significance (P\%). Experiments 1959-1962. $N=n i$ trogen supply, $P=$ plant density

\begin{tabular}{llll}
\hline Experiments in & 1959 & 1960 & 1961
\end{tabular}

Total tuber yield (fresh weight; Fig. 1)

$\begin{array}{lrlcc}\mathbf{N} & 2.5 & 1 & 2.5 & 0.1 \\ \mathbf{P} & 0.1 & 0.1 & 0.1 & 0.1 \\ \mathrm{NP} & >25 & 5 & 10 & 10\end{array}$

Yield of tubers $>35 \mathrm{~mm}$ (fresh weight; Fig. 2)

$\begin{array}{lclcc}\mathbf{N} & 10 & 1 & 5 & 0.1 \\ \mathbf{P} & 0.1 & 0.1 & 0.1 & 0.1 \\ \mathrm{NP} & >25 & 5 & 10 & 10\end{array}$

1 Fourth lifting on October 9th 
De Steeg -1959
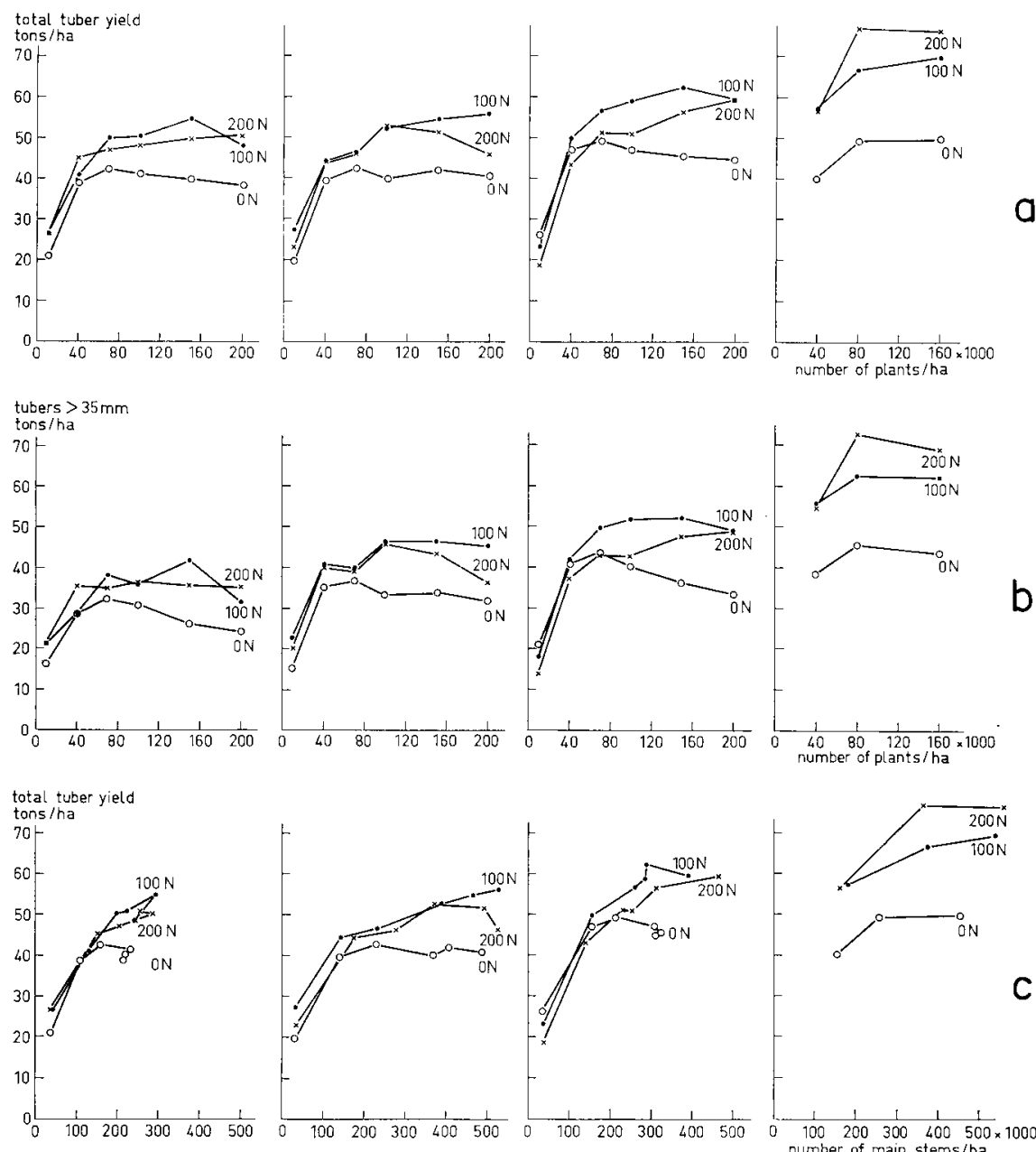

Hummelo- 1962
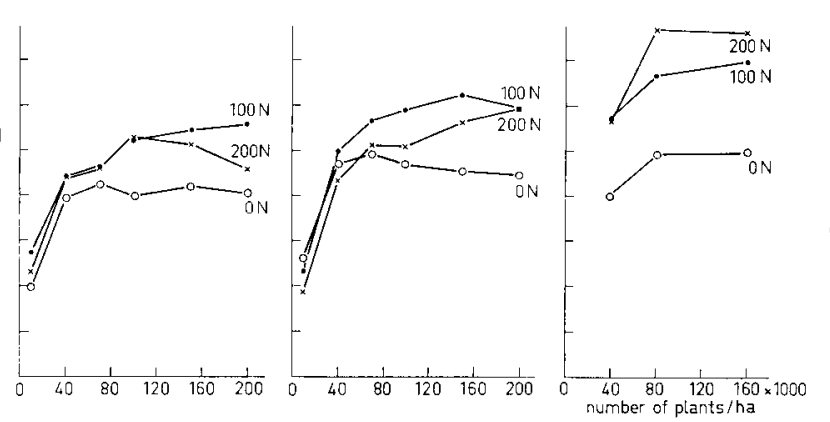

$b$

C

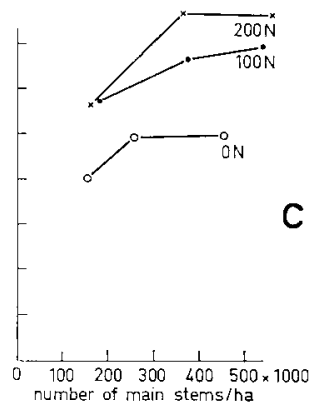

Fig. 1 Total tuber wield (a) and (b) yield of tubers $>35 \mathrm{~mm}$ at the end of the growing period in 4 experiments at different plant densities and nitrogen levels; $(c)$ total tuber yield plotted against the number of main stems per ha. Fresh weights: 1 ton $=1000 \mathrm{~kg}$. Nitrogen levels in $\mathrm{kg} / \mathrm{ha}$. Levels of significance: see table 1 .

nitrogen was applied $(40,000-50,000 \mathrm{~kg} / \mathrm{ha})$, indicating that in all cases the soil supplied sufficient nitrogen for the growth of a productive crop.

The response to $100 \mathrm{~kg}$ nitrogen/ha was evident in all experiments and larger at high than at low plant densities. In the experiment of 1962 also $200 \mathrm{~kg}$ nitrogen increased the yield significantly in comparison with $100 \mathrm{~kg}$ nitrogen at the higher plant densities. In contrast to the other years conditions in 1962 were generally favourable for undisturbed growth, also in the last part of the growing period; in 
most plots complete maturity was not even achieved on the last lifting date. In the other years however $200 \mathrm{~kg} \mathrm{~N} /$ ha did not increase tuber yield compared to $100 \mathrm{~kg}$ $\mathrm{N} /$ ha. Adverse factors for growth and production were: in 1959 (and also in 1962) Rhizoctonia attack early in the season, in 1959 also severe drought during the first months of summer (causing a late nitrogen reaction) and in 1960 and 1961 heavy Phytophthora attack when the foliage was still green in the second part of the summer; in both years the haulms were killed before maturity by chemical spraying.

The favourable influence of a high nitrogen supply especially at high plant densities was clearly visible in the experiment of 1962. High plant densities seem to have the opposite effect when no nitrogen is applied: a slight decrease in total tuber yield was seen in 1959 and 1961 when plant density was increased to over 70,000 plants/ha. This decrease was also visible in all four experiments for the yield of tubers $>35 \mathrm{~mm}$ (Fig. 1b).

\section{Tuber yield at different lifting times}

High nitrogen supply at high plant densities was more favourable for final tuber yield in the experiment of 1962 than in the experiments of 1959,1960 and 1961 . This difference may be explained by the longer vegetative period in 1962 than in the years before: in 1962 tuber yield increased still considerably after the end of August until October. The influence of the duration of the productive period can also be demonstrated by comparing the effects of nitrogen supply and plant density on tuber yield on different dates in the experiment of 1962; final tuber yields of this experiment have already been shown in Fig. 1.

Fig. $2 \mathrm{a}$ shows the tuber yields in this experiment at the successive lifting times. On June 22 tuberization at a plant density of 40,000 plants/ha was equal for the nitrogen and no nitrogen plots. At higher plant densities supplying nitrogen (100 or $200 \mathrm{~kg} / \mathrm{ha}$ ) resulted in a larger tuber weight already in this early stage. At the two following lifting times all nitrogen fertilized plots had a larger tuber yield than the no nitrogen ones, also at the lowest plant density.

An increase of the nitrogen supply from 100 to $200 \mathrm{~kg} \mathrm{~N} / \mathrm{ha}$ did not cause an increase in tuber yield at a plant density of 40,000 plants/ha at all lifting times. Also at the higher plants densities of 80,000 and 160,000 plants/ha no or little difference was found in tuber yield between the $100 \mathrm{~N}$ and $200 \mathrm{~N}$ plots but at the final lifting the high nitrogen plots had a distinctly higher tuber yield than the $100 \mathrm{~N}$ ones at these high plant densities. The difference between the third and fourth lifting time was highly significant $(\geqslant 99 \%)$.

The yields of marketable tubers ( $>35 \mathrm{~mm}$; Fig. 2b) in the experiment of 1962 showed a corresponding interaction of nitrogen dose, plant density and lifting time to that of total tuber yield. On June 22 no tubers larger than $35 \mathrm{~mm}$ were present.

\section{The dry weights of the tubers}

In the experiment of 1962 the dry matter content of the tubers was also determined. The percentages of dry matter in the tubers were slightly larger $(0.5-1 \%)$ with $100 \mathrm{~kg} \mathrm{~N}$ than with $200 \mathrm{~kg} \mathrm{~N} /$ ha; plant density did not show a clear influence. The dry weights of the tubers per ha (Fig. 3a) show a similar picture as the fresh weights (Fig. 2a): the no nitrogen plots produced lower weights than the 100 and $200 \mathrm{~N}$ plots at all plant densities and lifting times. The $200 \mathrm{~N}$ plots showed a larger tuber dry weight than the $100 \mathrm{~N}$ ones only at high plant density at the latest lifting time. The difference in interaction of nitrogen supply and plant density between the 
June 22

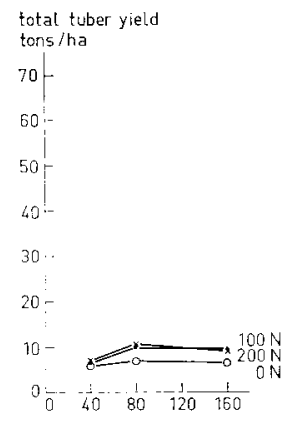

July 26
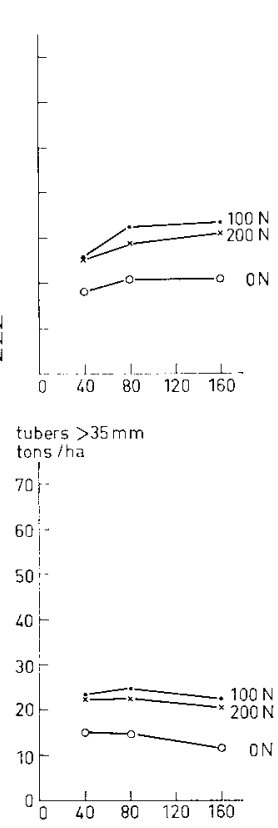

August 24
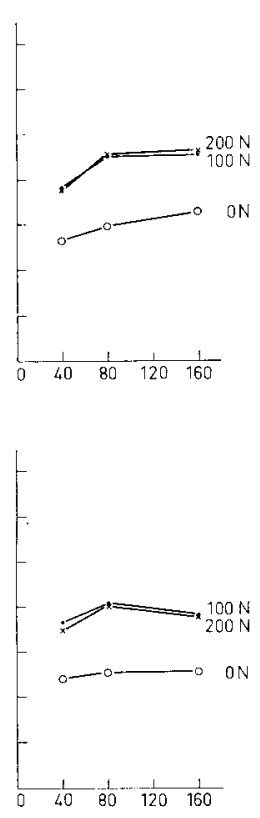

October 9
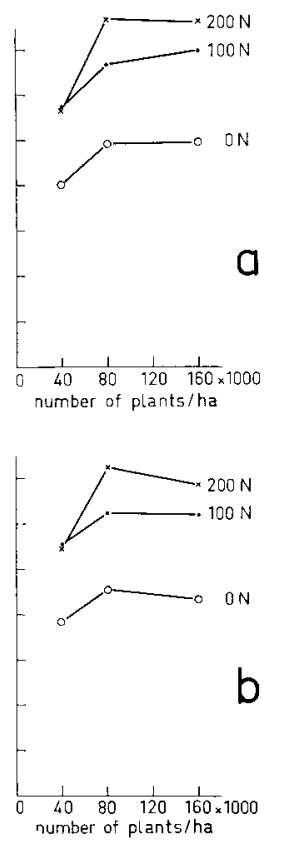

Fig. 2 Total tuber yield (a) and (b) yield of tubers $>35 \mathrm{~mm}$ (fresh weights) at 4 lifting times: 22 June, 26 July, 24 August and 9 October 1962, at 3 plant densities and 3 nitrogen levels. Levels of significance $=P \%(N=$ nitrogen supply, $P=$ plant density, $L=$ lifting time $)$ for total tuber yield: $N$ 0.1, P $0.1, L 0.1, N P$ 5, PL $0.1, N L 0.1, N P L 25$; tubers $>35 \mathrm{~mm}: N 0.1, P 0.1, L 0.1, N P 25, P L 0.1, N L 0.1, N P L 25$.

third and the fourth lifting time is highly significant $(\geqslant 99 \%)$.

Differences in growth and development

The above mentioned differences in tuber yield will have been caused by differences in growth and development of foliage and tubers at different nitrogen levels and plant densities. Some observations made during the experiments will be discussed here.

Number of stems. The interaction of nitrogen and plant density may perhaps be explained by the influence of the nitrogen dose on the number of stems per plant or per hectare. At increasing plant density the total number of stems per hectare generally increased. In the experiments of 1959 and 1961 this number did not further increase at more than 100,000 plants per hectare in the no nitrogen plots; the occurrence of Rhizoctonia may have inhibited such an increase.

Increasing nitrogen supply - especially from no nitrogen to $100 \mathrm{~kg} \mathrm{~N} / \mathrm{ha}$ - increased usually the number of stems per ha, counted at the end of the growing period. This difference may be attributed to competition for nutrients between the stems at low nitrogen levels. However, this increase did not influence the effect of nitrogen supply and plant density on tuber yield (compare Fig. 1c with 1a). 

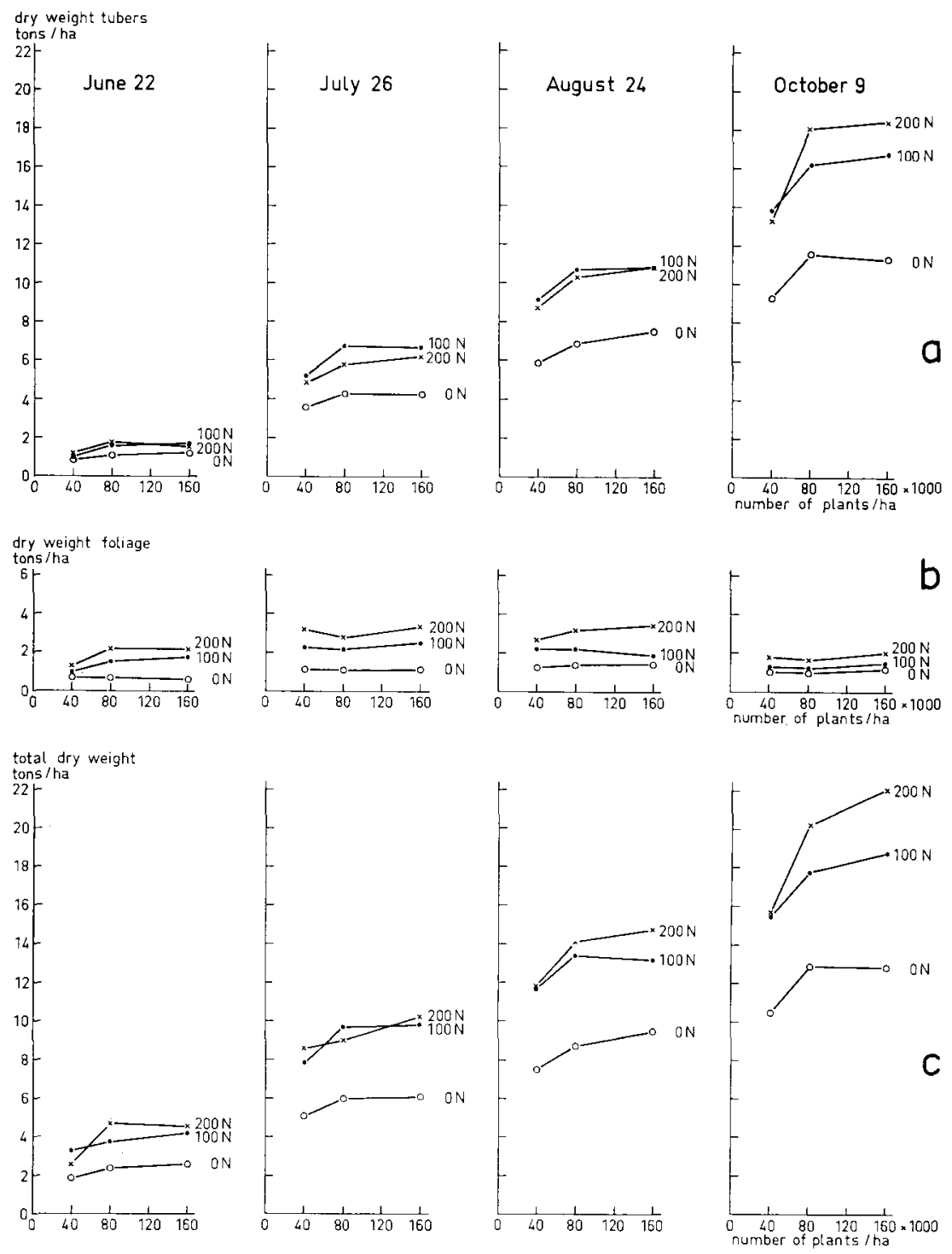

Fig. 3 Tuber dry weight (a), foliage dry weight (b) and total dry weight (c) at 4 lifting times; further as Fig. 2. Levels of significance $(P \%)$ for

tuber dry weight: $N 1, P 0.1, L \quad 0.1, N P 10, P L \quad 0.1, N L \quad 0.1, N P L>25$;

foliage dry weight: $N$ 0.1, P $0.1, L \quad 0.1, N P \quad 5, P L \quad 0.1, N L \quad 0.1, N P L>2,5$;

total dry weight: $N$ 0.1, P $0.1, L \quad 0.1, N P 2.5, P L \quad 0.1, N L \quad 0.1, N P L>25$.

Foliage growth and soil covering. High plant density increased early length growth of the stems, especially with high nitrogen supply.

The degree of soil covering ( = the percentage of the soil surface covered by foliage) 
Table 2 Degree of soil covering (percentage of soil surface covered by foliage). Experiment 1962

\begin{tabular}{cccc}
$\begin{array}{c}\text { Nitrogen dose } \\
(\mathrm{kg} N / \mathrm{ha})\end{array}$ & $\begin{array}{c}\text { Plant density } \\
(\text { number of plants } / \text { ha })\end{array}$ & \multicolumn{2}{c}{ Degree of soil covering } \\
\cline { 3 - 4 } & 28 May & 5 June \\
\hline 0 & 40,000 & 7 & 9 \\
0 & 80,000 & 12 & 14 \\
0 & 160,000 & 17 & 22 \\
100 & 40,000 & 13 & 15 \\
100 & 80,000 & 21 & 25 \\
100 & 160,000 & 28 & 36 \\
200 & 40,000 & 11 & 16 \\
200 & 80,000 & 24 & 34 \\
200 & 160,000 & 39 & 48 \\
\hline
\end{tabular}

during the first stages of growth increased with increasing nitrogen supply or plant density (Table 2). In this respect an interaction of nitrogen supply and plant density is indicated: the effect of nitrogen seems to be the largest with high plant density and an increase in plant density seems to be somewhat more effective at the high nitrogen doses than at the lower ones.

Branching and lodging of the stems. With increasing plant density the number of large branches per main stem decreased. An increase in nitrogen supply on the other hand increased branching. The nitrogen dose did not clearly change the effect of plant density on branching. The highest degree of branching was found with high nitrogen supply at low plant density. High plant density partly counteracted the effect of high nitrogen supply (Table 3). Branching was not influenced by lodging, which occurred at later growth stages in these experiments.

Lodging increased with increasing nitrogen supply. The degree of lodging was mostly higher at high than at low plant density (Table 4). In other experiments however an

Table 3 Degree of branching of the stems. Number of branches $>2 \mathrm{~cm}$ as percentages of the total number of buds per main stem. Experiment 1962

\begin{tabular}{ccccc}
\hline $\begin{array}{c}\text { Nitrogen dose } \\
(\mathrm{kg} N / \text { ha })\end{array}$ & $\begin{array}{c}\text { Plant density } \\
(\text { number of plants } / \text { ha })\end{array}$ & \multicolumn{3}{c}{ Degree of branching } \\
\cline { 3 - 5 } & & 22 June & 21 August & 9 Oct. \\
0 & 40,000 & 9.6 & 12.0 & 14.4 \\
0 & 80,000 & 6.3 & 5.9 & 7.9 \\
0 & 160,000 & 0.0 & 5.2 & 9.7 \\
100 & 40,000 & & & \\
100 & 80,000 & 32.8 & 31.8 & 32.0 \\
100 & 160,000 & 26.8 & 24.1 & 13.7 \\
& & 10.4 & 16.5 & 11.7 \\
200 & 40,000 & & & \\
200 & 80,000 & 45.3 & 44.0 & 44.0 \\
& 160,000 & 17.5 & 29.0 & 29.5 \\
& & 10.8 & 20.4 & 10.3 \\
\hline
\end{tabular}


Table 4 Degree of lodging. Experiment 1962

$0=$ no lodging $; 1=$ only some stems bent at the base; $5=$ lodging is apparent, but not all stems lying flat; $8=$ nearly all stems lying flat $; 10=$ all stems lying flat

\begin{tabular}{cccc}
\hline $\begin{array}{c}\text { Nitrogen dose } \\
(\mathrm{kg} N / \mathrm{ha})\end{array}$ & $\begin{array}{c}\text { Plant density } \\
\text { (number of plants/ha) }\end{array}$ & \multicolumn{2}{c}{ Degree of lodging } \\
\cline { 3 - 4 } & & 27 August & 10 Sept. \\
\hline 0 & 40,000 & 0 & 0 \\
0 & 80,000 & 0 & 0 \\
0 & 160,000 & 0 & 0 \\
100 & 40,000 & 0 & 1 \\
100 & 80,000 & 0 & 2 \\
100 & 160,000 & 0 & 2 \\
200 & 40,000 & 2 & 6 \\
200 & 80,000 & 5 & 7 \\
200 & 160,000 & 9 & 9 \\
\hline
\end{tabular}

increase of plant density seemed to reduce lodging. The data do not indicate an unfavourable influence of lodging on tuber yield.

Leaf senescence. The experiments of 1959, 1960 and 1961 did not produce reliable data on leaf senescence owing to disturbance by drought or early death by Phytophthora. In the experiment of 1962 an increased nitrogen supply delayed senescence at low plant density. The effect of plant density was only visible at high nitrogen levels; the plants died somewhat earlier at high than at low plant density. This effect was masked by the regrowth of the foliage on September 24th, especially of the high nitrogen - high plant density plots (Table 5).

Table 5 Degree of senescence. Experiment 1962

\begin{tabular}{ccccc}
\hline $\begin{array}{c}\text { Nitrogen dose } \\
(\mathrm{kg} N / \mathrm{ha})\end{array}$ & $\begin{array}{c}\text { Plant density } \\
\text { (number of plants } / \text { ha) }\end{array}$ & 10 Sept. & 24 Sept. & 9 Oct. \\
\cline { 3 - 4 } 0 & 40,000 & 6 & 6 & 7 \\
0 & 80,000 & 7 & 6 & 7 \\
0 & 160,000 & 6 & 6 & 7 \\
100 & 40,000 & 6 & 5 & 7 \\
100 & 80,000 & 5 & 6 & 7 \\
100 & 160,000 & 6 & 7 & 7 \\
200 & & & & \\
200 & 40,000 & 3 & 3 & $4-5$ \\
200 & 80,000 & 4 & 3 & 7
\end{tabular}

$5=$ basal part of the stems all leaves dead, middle part many yellow leaves; $7=$ basal and middle part all leaves dead, upper part yellow-green leaves; $10=$ plants completely dead 

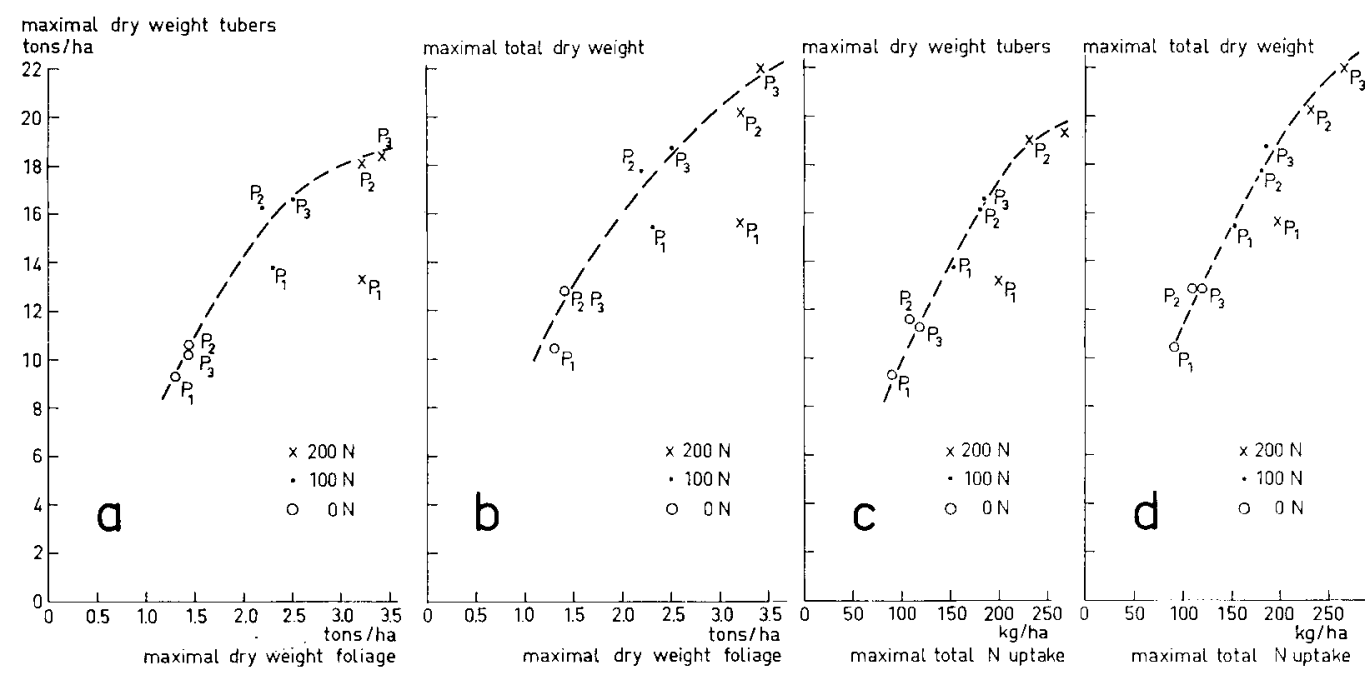

Fig. 4 The relation between maximal foliage dry weight and maximal tuber dry weight (a) and maximal total dry weight (b); the relation between maximal total $N$ uptake and maximal tuber dry weight $(c)$ and maximal total dry weight $(d)$. Experiment 1962 , plant densities $P_{1}, P_{2}, P_{3}: 40,000$, 80,000 and 160,000 plants per ha respectively.

Production and distribution of dry matter. The graphs for dry weights of tubers and total dry weights in the experiment of 1962 (Fig. 3a and 3c) showed good similarity. Differences in total dry matter between no nitrogen and nitrogen fertilized plots and between low and high plant densities are found already at early growth stages: these differences increased later in the season. The $200 \mathrm{~N}$ plots produced more dry matter than the $100 \mathrm{~N}$ ones in the last part of the growing period, but only at the high plant densities. The interaction of nitrogen supply and plant density on total dry weight is significant $(\geqslant 97.5 \%)$. The maximal dry weight of the foliage showed good correlations with the maximal dry weight of the tubers (Fig. 4a) and

June 22

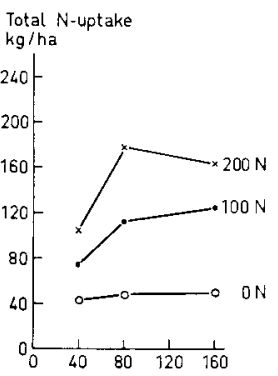

July 26

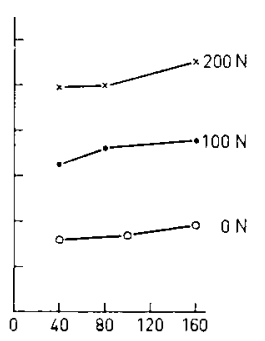

August 24

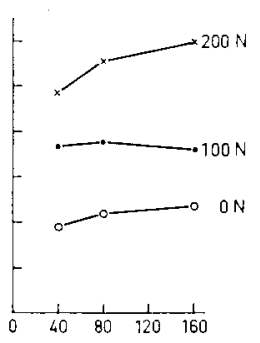

October 9

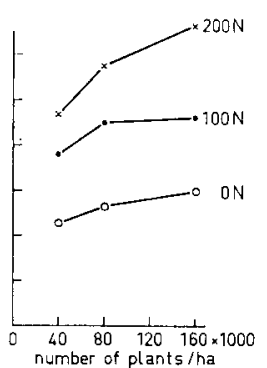

Fig. 5 Total $\mathrm{N}$-uptake in $\mathrm{kg} / \mathrm{ha}$ at 4 lifting times. Experiment 1962. Further as Fig. 2. Levels of significance (P\%): N 0.1, P 0.1, L 0.I, NP I, PL 5, NL 2.5, NPL 25. 
with the maximal total dry weight (Fig. 4b), except in the high nitrogen - low plant density plots $\left(=\times P_{2}\right)$. In these plots the lush growth of foliage was unfavourable for total dry matter and tuber production.

Nitrogen uptake. In the experiment of 1962 the nitrogen contents of foliage, tubers and other underground parts were determined. Total nitrogen uptake was larger at high than at low plant density (Fig. 5) at early and late growth stages. Tuber dry weight and total dry weight were correlated with nitrogen uptake, only the high nitrogen - low plant density plots produced lower final tuber yields than could be expected according to the nitrogen uptake (Fig. 4c and 4d).

\section{Discussion and conclusion}

The interaction of nitrogen and plant density was treated in earlier publication. Most experiments in 1940-1942, published by Reestman and Van Dobben (1943) did not show an interaction of nitrogen and spacing, perhaps due to the small differences in plant density and nitrogen dosage in these experiments. Ware (1937) increased the yield of no. 1 potatoes by increasing the fertilizer rate (the $N$ supply ranged from 66 to $130 \mathrm{~kg} \mathrm{~N}$ per hectare, $\mathrm{P}$ en $\mathrm{K}$ were varied at the same rate). The influence of the fertilizer rate was larger at higher plant densities than at lower ones (plant density ranging from 21,000 to 54,000 plants per hectare, with seed pieces of 1 ounce). The optimum density for the yield of no. 1 potatoes shifted also to a somewhat higher plant density with increasing fertilizer rate.

Van Burg (1967) found at an early lifting date an increase in tuber yield of the early variety Sirtema by increasing the nitrogen dose from 120 to $180 \mathrm{~kg} \mathrm{~N} / \mathrm{ha}$ at densities of 50,000 to 70,000 plants/ha, but no increase at 40,000 plants/ha. In another experiment he also found an increased response to nitrogen at higher plant densities when small seed tubers were used; but not with large seed tubers, which indicates that there is an optimal number of stems per hectare.

In our experiments of 1959-1961 the effect of plant density could clearly be demonstrated: a considerable increase in total tuber yield by an increase from 10,000 to 40,000 plants per ha; a smaller increase by $70,000-100,000$ plants/ha; and at very dense planting a decrease in yield when no nitrogen was supplied, or a small or no increase with nitrogen doses of 100 and $200 \mathrm{~kg} \mathrm{~N} / \mathrm{ha}$. The optimal plant density was increased by a nitrogen dose of $100 \mathrm{~kg} \mathrm{~N}$ compared to no nitrogen supply. In other words plant density should be less with a low nitrogen supply than with a normal one. A further increase of the nitrogen supply to $200 \mathrm{~kg} \mathrm{~N} /$ ha did not change the optimal plant density in these experiments.

An increase in nitrogen supply was mainly effective at high plant densities, and with a long growing period the foliage was productive until October and tuber yield increased by a high nitrogen dose at high plant densities. In the experiments of 19591961 , however, the growing period was relatively short and thus a nitrogen dose of $200 \mathrm{~kg} \mathrm{~N} /$ ha did not increase tuber yield compared to $100 \mathrm{~kg} \mathrm{~N} /$ ha. The importance of a long growing period was also found by Van Burg (1967) in his trial with industrial potatoes (variety Mentor), in which the interaction of plant density and nitrogen supply was visible only in late liftings.

One may try to explain these differences in tuber yield by the different growth of the foliage and the tubers at different nitrogen levels and plant densities. Nitrogen 
promotes growth of the foliage in the beginning, but may have a retarding effect on tuber initiation and growth (Werner, 1934).

The effect of nitrogen supply and plant density on the tuber bulking rate during the greater part of the growing period seems to be small in most cases, only with no nitrogen supply the tuber bulking rate was distinctly lower than in the other treatments. The different length of the productive period of the foliage and of the tuber bulking period will be still more important in determining tuber yield, the growth rate of tubers will decrease at low nitrogen levels in the later part of the season.

\section{Acknowledgements}

Many thanks are due to Mr. S. Algra for carrying out the field experiments and Mr. C. A. Hoveyn for the statistical analysis.

\section{References}

Burg, P. F. J. van, 1967. Relation of rate of nitrogen fertilization, seed spacing and seed size to yield of potatoes. Neth. Nitrogen Techn. Bull. 4: 1-30.

Klapp, E., 1950. Kartoffelbau. Schriften über neuzeitlichen Landbau. Eugene Ulmner, Stuttgart zZ Ludwigsburg.

Paauw, F. van der, 1962. Periodic fluctuations of soil fertility, crop yields and of responses to fertilization effected by alternating periods of low and high rainfall. Plant and Soil 17: 155-182.

Reestman, A. J., 1953. Is pootgoed van de kleine maat $(25 / 28 \mathrm{~mm})$ in de praktijk bruikbaar? Landbouwvoorl. 10 : 143-154.

Reestman, A. J. and W. H. van Dobben, 1943. Is wijziging van het aantal planten gewenst bij de huidige schaarste van meststoffen? Med. Landbouwvoorlichtingsdienst: $257-262$.

Reestman, A. J. and C. T. de Wit, 1959. Yield and size distribution of potatoes as influenced by seed rate. Neth. J. Agric. Sci. $7: 257-268$.

Roztropowicz, S., 1965. Die Abhängigkeit des Kartoffelertrages von der Grösse der Pflanzkartoffeln. Intern. Zeitschr. der Landwirtschaft : 43-45.

Tamm, E., 1950. Über Beziehungen zwischen Witterungsverlauf und Ertragsleistung bei landwirtschaftlichen Kulturpflanzen im Land Brandenburg. Zeitschr. Acker- und Pflanzenbau 92 : $450-465$.

Ware, L. M., 1937. Interrelation of spacing of seed piece and rate of application of fertilizer in the production of potatoes in Alabama. Am. Potato J. 14: 355-362.

Werner, H. O., 1934. The effect of a controlled nitrogen supply with different temperatures and photoperiods upon the development of the potato plant. Agric. Exp. Station Nebraska Res. Bull. $75: 1-132$

Wit, C. T. de, 1960. On competition. Versl. Landbouwk. Onderz. 66.8: 1-82. 